\title{
Preliminary Study of Wii Remote-Based Interactive Desk Screen Usage in Universitas Multimedia Nusantara
}

\author{
Dodick Z. Sudirman and Dymitri Y. Sarah
}

\begin{abstract}
On 2008, Johnny Chung Lee from Carniege Mellon University introduced a technology that uses Wii Remote called Low-cost Interactive Whiteboard (LCIW). During its study of usage in Universitas Multimedia Nusantara (UMN), it is found that one of LCIW weakness is the stability of the technology when it is moved from one place to another. S.N. Cheong has developed a variation of Wii Remote implementation by designing it as a desk. Study designed and developed a table as a teaching station that can be used to assist teaching in the class in the hope to increase teaching experience. Combining the design of the teaching station with previous developed software and hardware used for the implementation of LCIW, UMN starts to develop Interactive Desk Screen (IDS) and study its usage. The study shows that IDS have a positive responds from teachers and students based on the parameter of Student Engagement, Student Behavior, Student Learning, Responding on Teacher/Student Use and Student/Teacher Satisfaction.
\end{abstract}

Index Terms-Wii remote, interactive screen, low-cost interactive whiteboard, teaching tools.

\section{INTRODUCTION}

In the year of 2010, by considering the rise of tablet PC and tablet technology Cheoung, Yap and Chan from Multimedia University (MMU) in Malaysia developed a cost effective wiimote-based Multi-Touch Teaching Station [1]. The design of the teaching station is similar to the design of desk-based Microsoft Surface [1]. The teaching station is developed based on Johnny Chung Lee Wii Remote hack by combining it with infra-red pen, projector and Bluetooth-equipped computer.

Unlike Johnny Chung Lee design, they don't interact with the screen in the whiteboard but in a modified desk and a infra-red ring for touch screen instead of pen. MMU's teaching station has been tested in the class and has received a positive responds [1]. The instructor is able to be more expressive with the content in the screen by interacting directly with the content in the screen [1]. Unfortunately, the instructor feels it's uncomfortable to use the ring to interact with the screen [1].

Universitas Multimedia Nusantara as an academic institution has always been trying to find new approach in improving the teaching experience in the class. This is an attempt not only to answer the problem that the teacher have in the class but also the student involvement problem [2]. Previously UMN have a study to implement Low-cost Interactive Whiteboard (LCIW) that is originally designed by

Manuscript received May 7, 2013; revised July 4, 2013.

The authors are with ICT Faculty - Universitas Multimedia Nusantara (e-mail: dzsudirman@gmail.com).
Johnny Chung Lee [3]. The research conclude the ineffectiveness in the design of the pen, most tester prefer to use the pen naturally by not pushing the button but pushing the pen into the board [4]. In its usage, LCIW also reported to be hard to implement as a portable technology [4] that can be moved from one classroom to another. By modifying the hardware and the software developed for the implementation of LCIW in UMN into an interactive desk screen, it may be able to remove the problem of portability.

\section{LiterATURE STUDY}

As the legacy device, LCIW has been developed and researched by Stenley Timex for Universitas Multimedia Nusantara [4]. One of the main problems of the device is because of its instability when being moved from one class to another 4]. S. N. Cheong, W. J. Yap and M. L. Chan have developed a teaching station which has similar purpose of function similar to IDS.

The research of LCIW usage has been done by Vo Tan Dung in Vietnam, by using the parameter of Student Engagement, Student Behavior, Student Learning, Responding on Teacher/Student use and Student/Teacher satisfaction he has discovered the responds of LCIW usage is positive [5]. Previous parameter used to assess the usage of LCIW will be used as the basis of survey question to the user regarding Interactive Desk Screen.

\section{DeVICE DESIGN AND DEVElopMENT}

Interactive Desk Screen (IDS) is a modification of Low Cost Interactive Whiteboard (LCIW). As previously stated, LCIW is consist of infrared pen, Bluetooth-enabled computer, Wii Remote and projector. IDS will have similar items but with additional item that are mirror, glasses, thin paper and modified desk. LCIW previously has been researched by Stenley Timex for its usage in Universitas Multimedia Nusantara [4]. One of the main problems found at the research is the instability of LCIW when being moved. The design of IDS (Fig. 1) will not only portable but also has a big enough screen that teacher will easily write or draw. As for its portability, the desk will be equipped with wheels.

As for the infrared pen, the design will combine the design from Johnny Lee's design schema [3], Stenley Timex's design schema [4] and Marttyn's design schema [6]. Johnny Lee's design (Fig. 2) schema used as the foundation of the infrared pen, as it is used originally for Low Cost Interactive Whiteboard (LCIW). Stenley Timex design (Fig. 3) schema will be used as are referenced to build the rechargeable battery Infrared pen, so users no longer need to replace the battery when the battery is discharged. This is advantageous 
because it can save expenses used for battery usage. Martin design (Fig. 4) is used to answer the problem for the users that is uncomfortable using the pen by pressing the left button and pushes the pen instead.

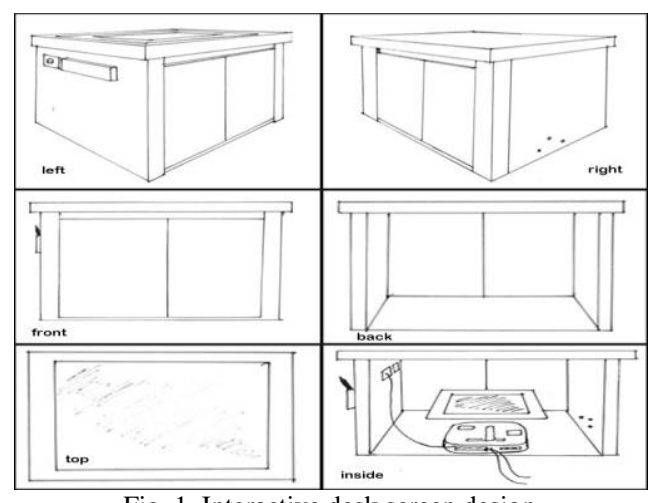

Fig. 1. Interactive desk screen design.

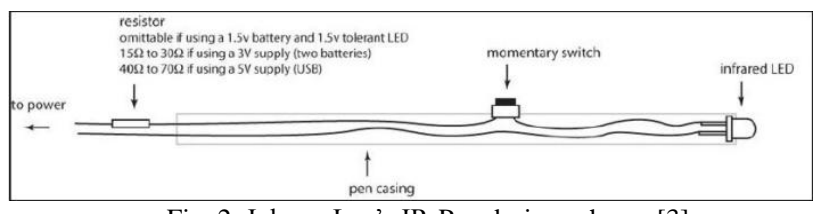

Fig. 2. Johnny Lee's IR-Pen design schema [3].

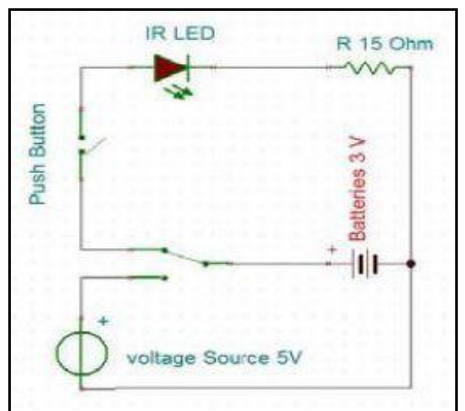

Fig. 3. Stenley Timex' IR-Pen design schema [4].

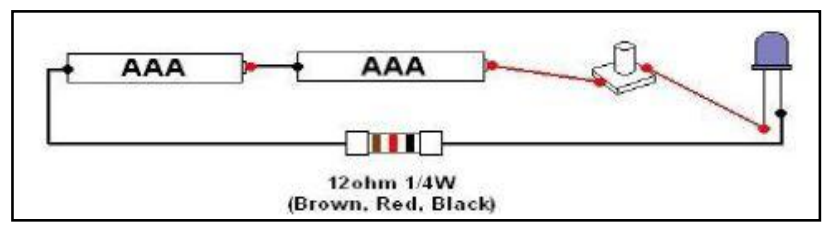

Fig. 4. Marttyn's IR-Pen design schema [6].

It takes one and a half month to develop the device. While the original design planned to build the desk from zero, we use an existing desk and modify it to fit into the desk design. We use glass and thin paper to be the place where the screen is projected while using common mirror find in the store to be.

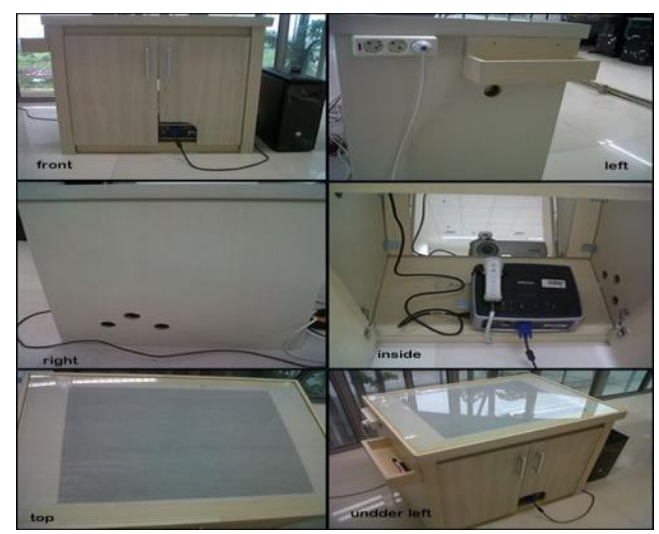

Fig. 5. Interactive desk screen (IDS) outcome.

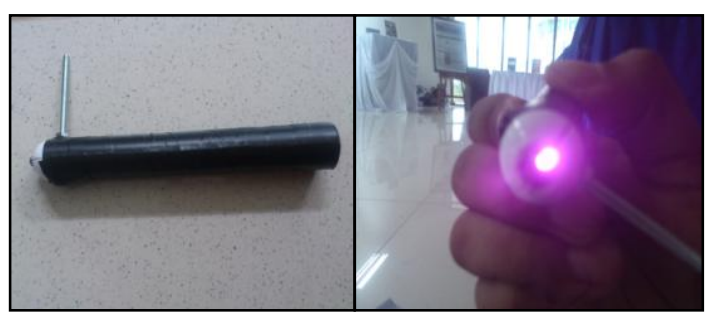

Fig. 6. Interactive desk screen Infrared pen.

\section{Evaluation}

Evaluation of Interactive Desk Screen (IDS) is completed by having the students, instructor, and employees in UMN to use it. As the foundation of the questionnaire we use Vo Tan Dung [5] parameter that is Student Engagement, Student Behavior, Student Learning, Responding on Teacher / Student Use and Student / Teacher Satisfaction. After trying IDS, users will be given questionnaires containing aspects of the variables use. Table I shows the result of the questionnaire, it is scaled from strongly disagree to strongly agree. Fig. 7 is the results of questionnaires that were distributed to 30 people during the research conducted on the use of Interactive Screen Desk at UMN.

TABLE I: INTERACTIVE DESK SCREEN QUESTIONNAIRES RESULT

\begin{tabular}{|l|c|c|c|c|c|}
\hline \multirow{2}{*}{ Variable } & \multicolumn{5}{|c|}{ Scale } \\
\cline { 2 - 6 } & $\begin{array}{c}\text { Strongly } \\
\text { Disagree }\end{array}$ & Disagree & Neutral & Agree & $\begin{array}{c}\text { Strongly } \\
\text { Agree }\end{array}$ \\
\hline $\begin{array}{l}\text { Student } \\
\text { Engagement }\end{array}$ & 0 & 4 & 7 & 15 & 4 \\
\hline $\begin{array}{l}\text { Student } \\
\text { Behaviour }\end{array}$ & 0 & 3 & 4 & 14 & 9 \\
\hline $\begin{array}{l}\text { Student } \\
\text { Learning }\end{array}$ & 0 & 2 & 7 & 13 & 8 \\
\hline $\begin{array}{l}\text { Responding on } \\
\text { Teacher/ } \\
\text { Student Use }\end{array}$ & 1 & 3 & 6 & 16 & 4 \\
\hline $\begin{array}{l}\text { Student/Teacher } \\
\text { Satisfaction }\end{array}$ & 1 & 3 & 4 & 18 & 4 \\
\hline
\end{tabular}

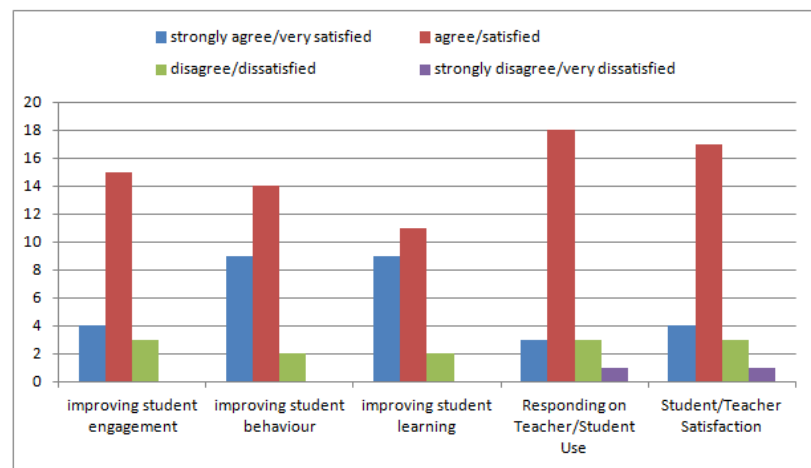

Fig. 7. Interactive desk screen questionnaires result.

\section{CONCLUSION}

The results of the preliminary study of the Interactive Desk Screen usage in Universitas Multimedia Nusantara are as follows:

1) We have concluded that students and faculty member agree that it can be used to support teaching activities in Universitas Multimedia Nusantara based on the student engagement, student behavior, student learning, studentlteacher satisfaction and studentlteacher usage.

2) Interactive Desk Screen is also improved previous 
research regarding the use of Wii Remote as a teaching support tools. It removes the problem of portability movement from one class to another.

\section{FUTURE DEVELOPMENT}

The following are suggestions for future research or development:

1) Develop an application that can manage thick and thin of the scratches produced by the infrared pen.

2) Develop software content that can be used in IDS for teaching.

3) Build a more compact infrared pen (adjusted with conventional pen size) so it's easier to use.

4) Making a more compact IDS table that gives more comfort and convenience when using the IDS.

5) Use mini projector with high quality lumens that the size of the IDS more compact and more economical.

\section{ACKNOWLEDGMENT}

We would like to thank Universitas Multimedia Nusantara that supported us morally and financially. We also would to thank you our fellow researcher in the subject of Wii hack in Universitas Multimedia Nusantara, Stenley Timex and Aditya Bona Ventura.

\section{REFERENCES}

[1] S. N. Cheong, W. J. Yap, and M. L. Chan, "Design and Development of a Cost Effective Wiimote-Based Multi-Touch Teaching Station," Malaysia.
[2] M. Yunus. (2011). Dalam. [Online]. Available: http://edukasi.kompasiana.com/2011/11/14/kenapa-kuliah-membosan kan/ Last Access: 10 February 2013.

[3] J. C. Lee. Low-Cost Multi-point Interactive Whiteboards Using the Wiimote. [Online]. Available: http://johnnylee.net/projects/wii/

[4] S. Timex, "Studi Awal Penggunaan Low-Cost Interactive Whiteboard pada Universitas Multimedia Nusantara," Universitas Multimedia Nusantara, 2012

[5] V. T. Dung, "Interactive Teaching \& Learning with Low-cost Interactive Smart Boards," Vietnam, 2009.

[6] Marttyn. How to make tip pressure pen. [Online]. Available: http://www.wiimoteproject.com/irpens/diy-how-to-make-tip-pressureir-pen

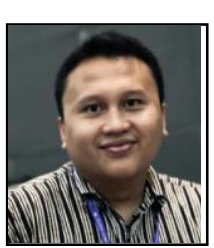

Dodick Z. Sudirman is one of computer science lecturer and researcher in Universitas Multimedia Nusantara. He was born in Ohio, U.S.A. on $30^{\text {th }}$ august 1985 but raised in Indonesia. He received his Master degree in Information Technology at Universitas Indonesia on 2007. Currently, his research is focusing on digital game and gamification. His field of study is web programming and game development. Currently his researches are focusing on digital game and gamification.

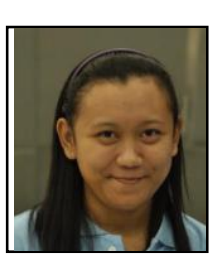

Dymitri Yulianti Sarah is one of computer engineering student in Universitas Multimedia Nusantara. She was born in Bekasi, Indonesia on $24^{\text {th }}$ May 1991. She is graduated from "67" Public High School on 2009. She's one of three student researchers who studied the use of Wii Remote usage for education in Universitas Multimedia Nusantara. In 2011, she becomes the head of Computer Engineering Student Association for a year. She's now focused on finishing her research on Principal Component Analysis to complete her study in Universitas Multimedia Nusantara. 